KEMAS 13 (1) (2017) 96-105
Jurnal Kesehatan Masyarakat

\title{
ANALYSIS OF NUTRITION CARE CHRONIC RENAL FAILURE PATIENTS WITH HEALTH TECHNOLOGY ASSESSMENT
}

\author{
Ahmad Yani $^{1 \bowtie}$, Gaga Irawan Nugraha ${ }^{2}$, Dewi Marhaeni Diah Herawati ${ }^{3}$ \\ ${ }^{1}$ Departemen of Nutrition Science, Sekolah Tinggi Ilmu Kesehatan Holistik, Purwakarta \\ ${ }^{2}$ Departemen of Medical Nutrition, Faculty of Medicine, Universitas Padjadjaran, Bandung \\ ${ }^{3}$ Departemen of Public Health, Faculty of Medicine, Universitas Padjadjaran, Bandung
}

\section{Info Artikel \\ Article History: \\ Submitted December 2015 \\ Accepted July 2017 \\ Published July 2017 \\ Keywords: \\ chronic renal failure; \\ health technology assess- \\ ment; nutritional care \\ DOI \\ http://dx.doi.org/10.15294/ \\ kemas.v13i1.4367}

\begin{abstract}
Declined in nutritional status of hospitalized Chronic Renal Failure (CRF) patients were due to nutrient intake inadequate which required special attention from the Hospital Nutrition Service Team. This study analyzed the nutritional service on hospitalized CRF patients in Dr. Hasan Sadikin Hospital, Bandung using Health Technology Assessment. The study was conducted in 2014. The study design mixed method with concurrent embedded strategies. The hospital management, nutritionist and hospitalized CRF patients were qualitative subjects, selected using purposive sampling. Quantitative subjects selected using total sampling were 25 patients. Food weighing were used to measure food waste. The nutritional services technology aspects especially nutritional care using PAGT has not been entirely done. Nutritional monitoring and evaluation have not been well programmed and scheduled. The collaboration of nutritional care team have not been optimal. The food service mechanism are quite good while its portions are standardized yet. According to patient's point of view towards food service quality, the food have less variety and taste. Total of cost damage from food waste are Rp.18.099.000,00 in a year. The lack of technological and organizational aspects can reduce the food service quality. According to the patient, the lack of food service quality will increase the food waste and total cost damage.
\end{abstract}

\section{Introduction}

Renal function disorder nowadays has been one of main community health problem in Indonesia. Based on 2013 basic health research, renal disease prevalence in Indonesia is $0.3 \%$ while the prevalence of CRF on Jawa Barat Province is $0.3 \%$. CRF is a condition in which renal function decrease chronically, progresively and permanently. The problem on CRF with hemodialysis is the high scale of malnutrition. The lack of energy and protein intake on the patient has significant relation with morbidity and mortality level (Kovesdy, 2010).

Research result in Brazil in 2007 stated that $80 \%$ CRF patient with hemodialysis are malnutritioned (Santos, 2013). Research at Dr. Sardjito Hospital, Dr. Jamil Hospital and Sanglah Hospital in 2002 indicated 28.2\% of patients had a declined nutritional status throughout hospitalized period (Budiningsari, 2004). Research at Dr. Moewardi District Hospital, Surakarta found out that $90.32 \%$ of CRF patient had high urea level caused by insufficient protein intake (Martini, 2010). Research at Dr. Hasan Sadikin, Bandung in 2013 indicated average energy and protein intake of CRF patient with hemodialysis is $2001 \mathrm{kkak} /$ day and $1.32 \mathrm{gr} / \mathrm{kg}$ BW/day. The low nutrition intake is triggered by the base diseases which are diabetes and hypertension (Herawati, 2014). Unfulfilled nutrition requirement influenced

\footnotetext{
Correspondece Address:

Jalan Veteran No. 272 Ciseureuh Purwakarta Jawa Barat Indonesia

Email : ahmadyani@holisticindonesia.com
} 
the function and recovery process of the organ as so lead to imun function declined (Lassen, 2006)

Well nutritional care could prevent and conserve nutritional status, attention is needed through optimalization of nutrition care service by hospital health team, so patient meals intake could be improved. The research at Gatot Soebroto Army Center Hospital, Jakarta in 2012 upon diabetes mellitus patient found out that standarized nutritional care process can improve protein energy intake and patient nutritional status (Yunita, 2012). Nutritional service whether in protein energy intake or meal management for hospitalized patient is a very significant factor assisting the healing process. If a patient obtains proper nutritional care when undergo the treatment then the healing process will be assisted, prevent complication, decrease morbidity and mortality thus could abbreviate hospitalize time and save the cost (Budiningsari, 2004).

The support of hospital policy and well cooperation between medical attendants and employee regarding nutrition care management are highly required to provide optimum nutritional service for the patients. Research at Dr. Moewardi District Hospital, Surakarta found out that on CRF patient average protein intake is $20.11 \mathrm{gr}$ and all respondents $(100 \%)$ are in insufficient intake cathegory due to improper dietary supplied (Martini, 2010). Cross sectional research at Dr. Mohammad Hoesin Hospital, Palembang obtained that hospitalized children had insufficient average energy and protein intake. This intake could be improved if there has been a cooperation among medical attendants in the hospital (Anzar, 2013). Meanwhile, qualitative research at Tugurejo Hospital, Semarang indicated that cooperation among medical attendants has been working but not yet supported by hospital policy as so the nutritional service management is not optimally conducted. An evaluation on hospital policy is expected to be able to improve quality of hospital nutritional service (Dewi, 2015).

Patient perception on meal service quality received is one of hospital nutritional service quality evaluation. Nutritional service quality can be viewed from patient's nutritional status alteration and quantity of food wastes. Quality of nutrition service is related with quantity of meals consumed by the patient. Patient will not consume disliked meal as so causing food wastes. Hospital minimum service standard regarding quantity of food wastes is $\leq$ $20 \%$ of served meal. Some researches indicated food wastes by hospitalized patient are higher than the number. Research in England in 1995 resulted that $27 \%$ patiens leftovered the meals due to quality concern (Wiliam, 2011). Research in Spain indicated food wastes caused by meal temperature is not satisfied the patients (Antonio, 2013). Other research said it has relation with disgestive disorder, meal aroma and meal from outside the hospital (Puspita, 2011)

Meals that does not consumed by the patient will generate a cost damage. Research at Dr. Sardjito Hospital in 2001 indicated food waste based on average inpatient class value IDR 2,952,160.00 per month or IDR $35,425,920.00$ per patient per year (Djamaludin, 2005). To reduce food waste and to improve the effectivity, can be done by managing quality of nutritional service through well planned meals, carefully consider of patient requirement and cooperation of all stakeholders. Motivate the patient to consume completely meals served by hospital could reduce the waste and prevent malnutrition. Patient medical cost can be reduced and hospitalize period can be abbreviated if patient's nutritional requirement is fulfilled (Kemenkes, 2013). The medical cost for CRF patient is expensive. Research at PKU Muhammadiyah Hospital on Yogyakarta in 2015 resulted that average medical cost for CRF level III is IDR 7,680,069.00土5,342,950.00. per patient per year while most of it is operation room cost and hemodialysis cost (Nugraheni, 2015).

Health Technology Assessment (HTA) is a systematic and comprehensive evaluation upon effect of a health technologi through four elements. They are technology, organization, patient and economy. Main purpose of HTA is to inform technology policy in medical treatment (Kristensen, 2001). Nutritional service which involve nutritional care and meals management is a health tecnology. Health Technology Assessment is the most proper way 
to evaluate nutritional care practice whether from aspect of technology, organization, patient and economical loss. Research in Denmark by Lassen (2006), for analysing nutritional care on ages patients hospitalized on three hospital by HTA approach, which comparing in progress nutritional care with nutritional care guide for hospitalized patient through aspects of technology, organization, patient and economy indicated that every hospital has advantage and disadvantage and none of them fulfilled all criteria in good hospital nutritional service guide. Research of nutritional care analysis on chronical renal failure inpatient in Indonesia, particularly at Dr. Hasan Sadikin Hospital, Bandung using HTA approach has never been done.

Based on above details, this research is important to view how the practice of hospitalized chronical renal failure patient nutritional care by using four elements with HTA approach. This research is conducted at Dr. Hasan Sadikin Hospital, Bandung, which is a third degree referenced hospital.

\section{Method}

Design used is mixed method with concurrent embedded strategy. Strategy of qualitative approach used is case study, data collection by in depth interview. Strategy of quantitative approach used is descriptive cross sectional. Subject of qualitative research are management team and hospital nutritional service attendant. Qualitative samples are obtained by total sampling on cronical renal failure patient by hemodialysis at Dr. Hasan Sadikin Hospital, Bandung. Sample obtained is 25 patients. Research period from October 23 to November 23, 2014. Quantitative data is obtained by primary and secondary data. Primary data is collected by meal weight scaling and calculating cost damage of food waste. Secondary data is taken from supporting documents. Qualitative data analysis consists of phases as follow : transcription, reduction, coding and cathegorization and then theme settlement. Quantitative data analysis conducted by descriptive method.

\section{Result and Discussion}

Nutritional service on CRF patient begins from new patient information by nurse to nutrition instalation. Inpatient nurse conducting nutritional screening to decide whether patient is at risk of malnutrition or not. Screening is conducted longest by 1 x 24 hours after patient come in to the hospital. Patient with well nutrition status or does not has malnutrition risk will be rescreened within 7 days. Nutrition screening method is conducted by viewing change of body weight, appetite, gastrointestinal disorder, and food intake by nurse. Patient is cathegorized as malnutrition risk if the score result of screening process is more than 2 . The nurse will reference the patient to the dietatry station for further nutritional treatment. Nutritional screening is very important considering CRF patient has a complex disease problem, start from decrease appetite and gastrointestinal disorder, as said by the informant below :

"CRF is usually being screened first. Initiate screening data collected is analyzed or added if required. If patient feel nausea, it is more difficult, thus the question is raised from the beginning whether there is problem with the food, umm.. and the nausea. Whether the menu need to be changed to fulfill daily intake requirement" (Informant 1)

Nutritional care mechanism on CRF patient begin from doctor in charge write a diet order to nutrition department. Nutrition department translate nutrition requirement to meal menu, then send it to meal preparation and service department. Nutrition department, in this case nutritional care subdepartment conduct a nutritional study to decide nutrition requirement on hospitalized CRF patient based on NCP. The nutritional study process for CRF patient who come to the hospital during dietary operational hour will be done by the day after. Recommendation of CRF patient diet based on early dietary prescription issued by the doctor in charge or nurse so it is possible that improper dietary service is given. It can be identified from interview result as follows :

“... since initiate diet prescription done by nutritionist can also be done by the doctor in charge or nurse ... so if it come from the doctor or 
nurse that not fully understand about the nutrition or special diet can be anything, such as standar meal service and then when the study came up umm.. the proper diet prescription will be issued ..." (informant 4).

PAGT conducted by dietician is recorded on patient status in integrated record. The dietician then doing coordination with the doctor and nurse in carrying out nutritional care whether directly or through integrated record, particularly when dietician composing a proper diet recommendation as patient requirement, base on PAGT. The coordination has not been optimalized as interview result below :

\begin{abstract}
"In my opinion, the collaboration has not been optimalized.. umm.. specially umm.. from medical perception.. I mean, it suppose to be in the service for the patient, isn't it.. all should provide the service for what is so called patient recovery..." (informant 3)
\end{abstract}

Advance nutrition care process on CRF patient is conducte in five phase in PAGT which are ADIME (Assessment, Diagnosys, Intervention, Monitoring and Evaluation). But not all patient obtain PAGT yet. PAGTbegin with nutritional assessment, nutritional diagnosys decision and specific meal/diet plan. Nutritional study process consists of nutritional history anamnesys, biochemistry data, medical test and procedure (include laboratory data), antropometric measurement, clinical examination and patient histrory. Nutritional diagnosys is conducted by indentify and name actual nutritional problem and/or in risk to ignite nutritional problem based on Nutritional Care Process standard belong to the hospital. Nutritional diagnosys divided into components of nutritional problem (problem), root cause (etiology) and signs and symptoms of problem (signs and symptoms)

After nutritional diagnosys process, an intervention plan begin which include intervention objective decision and diet prescription. CRF patient is ordered specific meal/diet according to the nutritional requirement, physical condition, phsycological condition, meal habit and appetite. Meal order is done by food preparation and distribution sub department. Meal order is processed on food preparation and distribution sub department then it is served to the CRF patient as ordered. The CRF patient and the family obtain nutritional education and counseling during the treatment period so they could understand, accept and carry out the diet.

Dietician will implements the intervention and communicate care plan to the patient, medical attendant or related staff through integrated record in patient status. Communication through integrated record is perceived as not effective yet, not all team read the recommendation result from integrated record lead to the recommendation of nutrition care team for the patient is not well applied, as interview result belows:

"... well, we use to ask, specially this related with the doctor as a leader, since we will, like change the diet like that.. So, if we do it.. we will write it, afterall we have had authority to write in the integrated record. We use to do it and also we entrust to the nurse. You know sometime the doctor do not read the whole.. umm.. record.. the record.." (Informant 4)

Next activity is to monitor and evaluate nutrition status to find out respond of patient/ client go the intervention and level of success. CRF patient is observed and evaluated physically, anthropometrically, laboratorically, etc related with the nutritional status. Monitoring is applied to evaluate appetite and food intake. When further action is required then CRF patient will be re evaluated. Else, the patient will obtain nutritional education/ counseling regarding diet application at home. When further outpatient treatment is required, patient will be referenced to nutritional counseling clinic. The CRF patient monitoring and nutritional evaluation has not been well applied, programmed and scheduled. It can be concluded from interview result as belows:

"The monitoring is conducted like umm... the next day or the day after. Probably two days later. Because if it is done every day, it will be sufficience 


$$
\text { compare to patient number." }
$$$$
\text { (Informant 5) }
$$

Hospital Nutritional Care (HRC) become an important part and base factor in patient treatment. Activity and coordination from various aspects should be done in giving nutritional care so the patient could obtain sufficient food intake during inpatient period at the hospital. The patient with malnutrition status require different nutritional care compare to the patient with over nutrition status, similarly the CRF patient require different nutritional care.

Nutritional screening process on CRF patient has been done well. Initial diet determination process still has the obstacle which is when the patient came other than operational hour of dietician, causing possibility of CRF patient obtain improper diet until further nutritional evaluation from dietician. Advance nutritional evaluation of CRF patient is processed by PAGT method and ADIME tool based on initiate screening from the nurse. PAGT process is recorded by dietician on patient status integrated form so all nutritional care team can read and provide feedback. Still, communication through integrated record is considered not optimum. The monitoring activity and nutritional evaluation of CRF patient is just the same. It has not been programmed and scheduled. Dietician number to provide nutritional care does not equal with the requirement, since not all level obtain PAGT. It indicate how complex the nutritional care chain in hospital as so need competence human resource of various qualification, need sufficient facility and infrastruture and hospital management and related stake holder support. Weak point on one of the chain of nutritional care will bring negative impact to patient nutritional intake and health status. If patient obtain proper nutrition care during medical treatment will assist the healing process, prevent complication, decrease morbidity and mortality. Therefore hospitalize period will be shorten and save hospital cost (Budiningsari, 2004; Santos, 2013).

Nowadays, in Indonesia, not many hospital apply a holistic care concept. It's a concept of integrated service and position the patient as a subject instead of an object. The staffs involved in patient medical care are the active healers involving patient and the family to responsible in health matter. Position the patient as a human and view the patient as an entity are expected to assist the healing process. Seamless communication between health attendant and patient provide comfortable feeling and motivation to heal (Rayner, 2011).

Actor in Nutritional Care Team (NCT) consist of doctor, dietician, nurse and pharmacy. Each has it's own role, yet NCT in particular for CRF patient has not been formed so coordination of CRF patient nutritional care is based on integrated record. Number of dieticians to do current nutrition care have not meet the requirement, as not all class obtain NCP yet. This is result from limitation of dietician number.

"...yet... since we do have limitation of nutritionist number in nutritional care service for inpatient and outpatient, then in the process not all patients obtain NCP... " (Informant $6)$.

Number of dieticians for inpatient rooms are 18 persons and 4 of the dietician serve the internal disease rooms. Based on report of Nutrition Department performance in 2014, average number of patients obtain the NCP reach 558 patients per month, with $87.7 \%$ malnutrition and $68 \%$ malnutrition risk. Number of dieticians on food service unit are 3 persons who in charge for supervision of meals preparation and distribution.

The existance of Nutritional Care Team at Dr. Hasan Sadikin Hospital in Bandung is form of support provided by hospital management in taking care of patients with malnutrition. But the team is only assigned to surgery patients, and have not been assigned to all patients including CRF patients. Role of Nutritional Care Team for CRF patient need to be well managed to give the patient an optimum nutritional care. Nutritional care will be carried out properly by coordination between various experts in the hospital. Communication between departments involved in nutritional care service is required to provide best nutrional care for the patient 
(Kemenkes, 2013). The problem in Dr. Hasan Sadikin Hospital in Bandung is unoptimum collaboration and team work of Nutritional Care Team particularly for CRF patient. Specific Nutritional Care Team for CRF patient need to be assembled, thus the communication is not limited only to integrated record but through more focus discussion forum. The activity of coordination and evaluation by Nutritional Care Team is very important to be improved, so the detail of root cause can be identified. The hospital management has enhanced all staff involved in health service. The enhancement particularly for those who involve in nutritional care by improving the education level from D1 to D3 and from S1 to S2. Improvement of education level of all staffs are highly related with improvement of nutritional care for the patient (Diez-Garcia, 2013).

Mechanism of meal service to CRF patient begin from meals request for patient submitted by nurse on each room and signed by head of room. Amount of meals requested is created as many as number of inpatients and diet decided by the doctor. The list then dispose to nutritional department and received by person in charge before 09:00. When there is a change in dietary recommendation above that time, then the room nurse with dietician must inform the nutritional department through dietary change form. Meal request and/or patient dietary change can be informed through phone call or verbal, yet it still not efficient since sometime the information is missing.

\begin{abstract}
"Like we already know which is given the intervention with this kind of diet with certain nutritional status, then we meet the collage from meals service so we inform.. umm... sometime just by phone sometime by written form..umm... this is part of the obstacle while the information does not reaches desired person.. so there is problem.. " (Informant 4)
\end{abstract}

Meals for CRF patient is delivered from nutrition department to the pantry in closed carriage by room nutriton attendant or house keeper or nurse in case of room nutrition attendant or house keeper is not available. Meals are prepared in portion in the room with specific portion standar or specific etiquette, so that the served food is in accordance with the patient requirement. But sometimes meals portion attendant prepare it without following the standard given, so the food served to the patient has too much portion. Meals service attendant delivers or distributes the food to all inpatient rooms. An hour after mealtime, the attendant will clear up the dishes where all cutlery will be taken to the kitchen to be washed. Meals service attendant always do patient identity verification before serving it. As interview result belows:

\section{“...After giving the meals to the patient, continue with rechecking whether we have new patient or there is patient who has not been served or missed. Eventhough we have new patient, we must ask the dietary nurse. We must re confirm.. " (Informant 7)}

The meals management should be attempt to improve and educate the patient so that food service in the hospital is in accordance with patient requirement and expectation. Meals arrangement at Dr. Hasan Sadikin Hospital, Bandung is conducted by self-management and semi outsourcing. The mechanism has been refer to Department of Health standard, begin from planning the menu, foodstuff requirement and budget, purchasing, budget receiving, storage and food preparation, distribution and recording, and reporting and evaluation. The mechanism of meals management is described in nutritional care guidance and hospital nutritional department organization. Distribution for CRF patient meals is arranged by decentralization system. Meals for patient is delivered from preparation station in the kitchen to inpatient room. The communication in the process to change CRF patient diet direction are still constrained. Meal portion attendant does not perform the task as determined standard, so that amount of food served to the patient oftenly too much in portion. The evaluation upon served menu has just been applied to non-diet patient while diet patient such as CRF patient has not been applied. Service is a series of intangible activities as result of the interaction between the patient and employee in order to solve patient problem 
(Mulyadi, 2013). Evaluation is expected to be applied to diet patient such as CRF patient by optimally involving the patient so that meals menu served as patient requirement and expectation.

Number of staffs on the nutrition department are 1 nutriton department head with education background of S2 in Public Health, 5 nutrition sub department head with education background of S2 in Public Health 2 persons and S1 Nutrition 3 persons. Strategic operational (SO) consists of Unit Head (SO1) 8 persons, person in charge (SO-2) 16 persons, administration (SO-3) 11 persons, administration (SO-4) 12 persons. Education background for SO-1 is graduate major in Public Health, S1 Nutrition 3 persons, Graduate major in education 1 person and D3 3 persons. Education background for SO-2 is D1 Nutrition and vocational high school, and SO-3 and SO-4 is D3 State Administration and high school.

Dr. Hasan Sadikin Hospital, Bandung since 2012 has implemented a service policy particularly for hospital nutritional care. It integrated with other health care in the hospital. The policy is aligned with Dr. Hasan Sadikin Hospital, Bandung preparation for 2015 hospital accreditation. Hospital management has involved all disciplines to provide patient care. The commitment is revealed in below interview result:

\begin{abstract}
“... so in composing medical care standard, we refer to clinical practise stated in the clinical pathway. So in taking care of the patients involving coleagues from nutrition department... so it is commitment of the hospital that nutritional care in one of important thing to do.. " (Informant 8)
\end{abstract}

The hospital management is currently improving the education of all human resources on various line of service, nutrition department is included in the program. The support for nutritional care given by hospital management is the approval on index of patient foodstuff price. The composing of foodstuff price index is based on the datas collected by nutrition department. The support in nutritional care service is the assemble of Nutritional Care
Team (NCT) signed by hospital director and Faculty of Medicine Padjadjaran University based on joint decree FK-RSHS No. 074/D.1$8-32 / \mathrm{V} / 2005$ and No.95/J.06.6.FK/Kep/ $\mathrm{KP} / 2005$. The objective of NCT establishment is to provide recommendation to Hospital Director regarding nutritional care service for every room and meal management, so the patient nutritional status can be improved. Nutritional care service is responsibility of nutrition department, but must be coordinate with Nutritional Care Team.

Hospital nutrition department has composed some SOP (Standard Operating Procedure). It consists of nutritional care service, menu arrangement precedure, production and distribution management procedure, meals and cutlery handling for patient with infectious disease, foodstuff storage and handling. The objective of SOP making is to integrate nutritional care with other service in the hospital. Head of Nutrition Department at the hospital has issued a policy that all nutritionist with no exception who serving meals management to perform nutritional care but with different numbers of patient so the main job is not disturbed. This policy is applied in order to improve dietician skill in patient nutritional care.

Evaluation on patient meals service quality is conducted by quality subdepartment and patient meals service. Evaluation of food service that has been done is customer satifaction survey on nondiet patient by distribute the patient meals service questionaire and measurement of left over food by comstock method, instead of patient interview result and food weight measurement. Generally CRF patients stated nutritional care is good enough, include how the meal is serviced, as below interview result:

"Well, here can be said that the menu is quite good.." (Informant 7).

The quality meal service must consider on time delivery in meal service. The meal service based on observation on CRF patient is always on time, the service attendant consider the CRF patient is required prompt service, so the meal service attendant always attempt 
to serve the meal for the patient on time. CRF patient confirmed it as belows:

$$
\begin{aligned}
& \text { “yes.. precisely on time.. no delays all } \\
& \text { this time..." (Informant } 8 \text { ) }
\end{aligned}
$$

Meal service at Dr. Hasan Sadikin Hospital refer to standard of hospital meal service guidance. Cutlery provided for CRF patient is avilable completely and compatible with the standard settled. The meal appearance served generally good particularly the cleanliness of the cutlery and dishes, as below interview result:

\section{"....... well it's good, clean and healthy.." (Informant 9)}

Good interpersonal relationship will result trust or credibility by giving sense of care to the patient. The meal service attendant will serve the patient politely and in accordance to regulation from nutrition department. The condition reflected in below interview result:

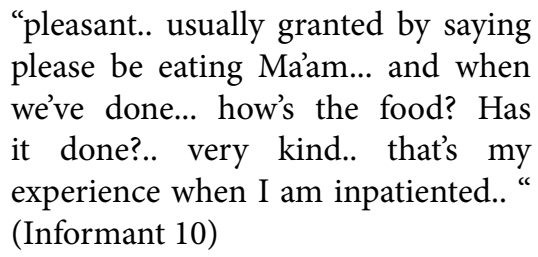

Meal menu for CRF patient at Dr. Hasan Sadikin hospital, Bandung is based on 10 days rotated menu. From the menu variation, it is good enough but CRF patient still desire an improvement of meal service, particularly in term of meal variation and taste.

\begin{abstract}
"It would be better if it does not one menu only for one kind of meal. Like the desert is always puding. Why don't serve fruits sometime.. yes, fruits will be good.." (Informant 11).
\end{abstract}

Less varied menu causing CRF patient does not finishes consuming the food and rather to buy food outside the hospital. So that the patient's food waste is high.

\footnotetext{
"It's good enough, well.. the taste is the most important thing. If the patient feel that the taste of the meal is bad.
}

what can we say.." (Informant 12)

Less tasty meal can reduce patient's appetite so that patient's food waste is high. So does the internal condition of the patient like anorexia and hemodialysis frequence could influence CRF patient food intake.

Quality of nutritional care can be seen by nutritional status change and quantity of food waste. Nutrition Department at Dr. Hasan Sadikin Hospital, Bandung has delivered a good meal service, though it has not met patient need and expectancy. Patient expectancy and satisfaction is a very subjective thing, it is intangible, changeable, and influenced by many factors, as many as condition in human life. The subjectivity can be decreased and even turns to objectivity while many person has identical opinion upon one thing. Patient perception on service quality is highly related with patient satisfaction (Sari, 2014). Based on direct evident (tangible) meal service provided by Dr. Hasan Sadikin Hospital, Bandung has had sufficient meal preparation facility and complete cutlery. Reliability of meal service attendant in performing the job is good and precisely on time. Respond to patient complain and change of dietary menu is fast. Meal service attendant is willing to hear patient complain for some times. One kind of empaty noticed by patient as understanding of patient need that is when the patient want a menu change.

The lack of menu variation felt by the patient reducing patient's appetite and lead to refuse to eat or finish the meal. Nutrition Department at Dr. Hasan Sadikin Hospital, Bandung has arranged well vary menu, yet one kind of meal that monotone which is porridge. Patient demand that it is replaced with rice as commonly consumed. Well coordination between nurse, dietician and meal service attendance in taking care of patient complain particularly the menu change from porridge to rice still need to be improved. Portion attendant during the process does not refer to proper size so it offtenly over served and finally result in high food waste. A standard in solving the problem found is required to improve quality of meal service. Martini (2010), said internal condition of CRF patient like decrease appetite, nausea, and regurgitate also influence 
Table 1. Quantitative Analysis of Cost damage from Chronic Renal Failure Food waste

\begin{tabular}{|c|c|c|c|c|c|}
\hline Mealtime & $\begin{array}{l}\text { Kind of } \\
\text { Foodstuff }\end{array}$ & $\begin{array}{l}\text { Served } \\
\text { amount } \\
\text { (gram) }\end{array}$ & $\begin{array}{l}\text { Food waste } \\
\text { (gram) }\end{array}$ & $\begin{array}{l}\text { Price per } \\
\text { Served (IDR) }\end{array}$ & $\begin{array}{l}\text { Cost damage } \\
\text { (IDR) }\end{array}$ \\
\hline \multirow[t]{3}{*}{ Breakfast } & Porridge/Rice & 222 & 98 & 4.889 & 575 \\
\hline & Meat & 49 & 2 & & \\
\hline & Vegetables & 130 & 67 & & \\
\hline Morning Snack & & & & 1.800 & 258 \\
\hline \multirow[t]{3}{*}{ Lunch } & Porridge/Rice & 237 & 64 & 4.229 & 523 \\
\hline & Meat & 47 & 2 & & \\
\hline & Vegetables & 124 & 62 & & \\
\hline Afternoon snack & & & & 1.840 & 102 \\
\hline \multirow[t]{3}{*}{ Dinner } & Porridge/Rice & 240 & 74 & 2.661 & 553 \\
\hline & Meat & 51 & 3 & & \\
\hline & Vegetables & 143 & 49 & & \\
\hline Evening Snack & & & & 0 & 0 \\
\hline Cost damage (IDR) & & & & & \\
\hline 15.419 & & & & & \\
\hline 2.011 & & & & & \\
\hline
\end{tabular}

Source: Processed Primary Data, 2014

patient appetite thus the food intake become insufficient. Provider must understand the patient stasus and requirement of and involve the patient to find an effective way for food service management so a trust each other relationship between provider and the patient is required. Intensive education regarding CRF disease condition and the importance of the meal for treatment process are expected to increase patient food intake and reduce the food waste (Anzar, 2013)

The weight scaling of food waste had been conducted to 25 CRF patients at Dr. Hasan Sadikin Hospital, Bandung for 2 days. The food waste beside causing patient requirement does not fulfilled also lead to hospital disadvantage

Average daily most food waste is vegetable, rice/porridge and meat. This is aligned with Djamaluddin research in 2001 at Dr. Sardjito Hospital, Yogyakarta indicated most food waste is vegetables $25,33 \%$, rice $23,1 \%$ and meat 21,8\% (Djamaludin, 2005). Average cost damage from food waste in one day is IDR $2,011.00$, in one month is IDR $1,508,520.00$ and in a year is IDR 18,099,000.00.
Cost damage of food waste by CRF patient is caused by patient appetite generally low due to body metabolism, food from outside the hospital and the portion of served meal does not follows the standard. The fundamental of appropriate service is conformed with the class and requirement. Proper services are proper menu, proper time, proper arrangement and proper amount. As resulted from research by Williams (2011), that the patient leftovers the meal due to the lack of quality meal served. To guarantee patient satisfaction by keep considering cost effectivity and efficiency is an objective of good quality standard according to the patient (Sulistiyorini, 2008). The settlement of gradualy individual-standar portion by considering patient ability is expected to be able to increase patient food intake and decrease quantity of food waste and cost damage.

\section{Conclusion}

Lack of technology aspect decreases quality of meal service thus increase the food waste and cost damage. The role of inpatient nutritional care organization consist of management and nutrition care team has not 
contributed to the improvement of nutritional care for chronic renal failure inpatient in the hospital. So does the lack of organization aspect. Unfavourable patient view to quality meal service could increase left over food and cost damage. The cost damage of food waste by chronic renal failure inpatient at Dr. Hasan Sadikin Bandung in a year is IDR 18,099,000.00. This research need further study with different case so that able to obtain a complete description of nutritional care process on a hospital. It is necessary to do a research on different site and case to enrich the insight in analyzing nutritional service on a hospital.

\section{References}

Antonio, Angel. 2013. Evaluation of Factors Affecting Plate Waste of Inpatients in Different Healthcare Settings. Nutrition Hospital, 28:419-27.

Anzar J, Pratignyo B, Nazir M. 2013. Profil Kecukupan Asupan Makanan pada Rawat Inap. Sari Pediatri, 14 (6): 351-56

Budiningsari RD, Hadi H. 2004. Pengaruh Perubahan Status Gizi Pasien Dewasa terhadap Lama Rawat Inap dan Biaya Rumah Sakit. Jurnal Gizi Klinik Indonesia, 1 (1):35-45

Dewi ES, Kartasurya MI, dan Sriatmi Ayun. 2015. Analisis Implementasi Pelayanan Gizi di RSUD Tugurejo Semarang. Jurnal Manajemen Kesehatan Indonesia, 3 (2): 91-8

Diez-Gracia R, Japur C, Medeiros M. 2013. Food and Nutritional Care Quality Indicator in Hospital. Jurnal of Hospital Administration, 2 (3):132-41.

Djamaluddin M, Prawirohartono EP, Paramastri I. 2005. Analisis Zat Gizi dan Biaya Sisa Makanan pada Pasien dengan Makanan Biasa. Jurnal Gizi Klinik Indonesia, 1: 108-12

Herawati DMD, Ariyanto EF. 2014. Kebijakan Medik pada Pasien Gagal Ginjal Kronik dengan Hemodialisis di RS Hasan Sadikin Bandung. Jurnal Kebijakan Kesehatan Indonesia, 3:6674.

Kementrian Kesehatan Republik Indonesia. 2013. Pedoman Pelayanan Gizi Rumah Sakit. Jakarta.

Kementrian Kesehatan Republik Indonesia. 2013. Riset Kesehatan Dasar. Jakarta

Kovesdy CP, Shinaberger CS, Zadeh KK. 2010 Epidemiologi of Dietary Nutrition Intake in ESRD. PMC, 4:353-8.

Kristensen FB, Horder M, Poulsen PB. 2011. Health
Technology Assessment Handbook. Edisi ke1. Denmark: Danish Institute for Health Technology Assessment

Lassen K, et al. 2006. Nutritional Care of Medical Inpatiens: A Health Technology Assessment. BMC Health Services Research, 6: 7

Martini, Endang NW, dan Mutalazimah. 2010. Hubungan Tingkat Asupan Protein dengan Kadar Ureum dan Kreatinin Darah pada Penderita Gagal Ginjal Kronik di RSUD Dr. Moewardi Surakarta. Jurnal Kesehatan, 3 (1): 19-26

Mulyadi D, Fadli UM, dan Ningsih FCK. 2013. Analisis Manajemen Mutu Pelayanan Kesehatan Rumah Sakit Islam Karawang. Jurnal Manajemen, 10 (3): 1203-19

Nugraheni DA, Suryanegara FDA, dan Putri MACW. 2015. Analisis Biaya Penyakit Ginjal Kronis Pada Pasien JKN Rawat Inap di Rumah Sakit PKU Muhammadiyah Yogyakarta. Rakernas \& PIT IAI 2016

Puspita DK, dan Rahayu RR. SR., 2011 FaktorFaktor yang Berhubungan dengan Perilaku Menyisakan Makanan Pasien Diit Diabetes Mellitus. Semarang: Jurnal KEMAS, 6 (2): 123-25

Rayner JA, Willis K, and Pirotta M. 2011. What's in a Name: Integrative Medicine or Simply Good Medical Practise. Family Practise, 28 (6):65560

Santos A, et al. 2013. Association Between The Level of Quality of Life and Nutritional Status in Patiens Undergoing Chronic Renal Hemodialysis. Journal Bras Nefrol, 4:279-88.

Sari AK, Wulandari RD. 2014. Penilaian Kepuasan Pasien Terhadap Mutu Pelaynan Instalasi Rawat Jalan RS H.S. Samsoeri Mertojoso Surabaya. Jurnal Administrasi Kesehatan Indonesia, 2 (4):235-42

Sulistiyorini C, Lestari T, dan Rohmadi. 2008. Tinjauan Faktor Penyebab Waktu Tunggu Pendaftaran Pasien Umum Rawat Jalan di Rumah Sakit Umum Daerah Sragen. Jurnal Kesehatan, 2 (1): 56-69

Williams P, Walton K. 2011. Plate Waste in Hospitals and Strategies for Change. The European E-Journal of Clinical Nutrition and Metabolism, 6 (6):235-41.

Yunita, Asdi AH, dan Susetyowati. 2012. Pelaksanaan Proses Asuhan Gizi Terstandar (PAGT) Terhadap Asupan Gizi dan Kadar Glukosa Darah Pasien Diabetes Melitus Tipe 2. Jurnal Gizi Klinik Indonesia, 10 (2): 82-91 